\title{
The Inevitability of Multinational Corporations towards Achieving Sustainable Development in Developing Economies: A Case Study of the Nigerian Economy
}

\author{
Hassan, Olanrewaju Makinde \\ Department of Business Administration, Faculty of Management Sciences, Kogi State University, Anyigba, Kogi State, \\ Nigeria,Email: olanrewajuhassan75@yahoo.com,Olanrewaju.hassan@zenithbank.com
}

\begin{abstract}
This paper dwells on the inevitability of multinational corporations in the sustainable development of developing economies, using Nigeria as a case study. Over the years and with the advent of globalization, multi-national corporations now move with ease across the world to economy of interest, most often times to developing economies. Obviously speaking and considering the huge amount and the technicalities involve in setting up these multi-nationals, it is obvious that the developing economies cannot do without them. The study made use of secondary data sourced from the Central Bank of Nigeria statistical bulletin and the National Bureau of Statistics between 1970 and 2011. The model for the study has as its dependent variable the Gross Domestic Product (GDP) and its explanatory variables were Foreign Direct Investment (FDI) into Nigeria. Using the Ordinary Least Square (OLS) multiple regression techniques; our study revealed that there is a strong positive relationship between the Nigerian Gross Domestic Product (GDP) and foreign Direct Investment (FDI). That is, the presence of FDIs has greatly impacted positively and significantly on the Nigerian economy given the period of study. This is true to apriori and theoretical propositions. The study, therefore recommended that efforts should be geared towards creating an enabling environment for FDI to thrive in the economy.
\end{abstract}

Key Words: Multinational corporations, developing economies, sustainable development, gross domestic product, foreign direct investment

\section{Introduction}

Despite the efforts of the developing countries and international organizations or the economic activities of Trans-National Corporations (TNCs), developing countries have remained poor and the progress in development is marginal. There are legion of possible causes that might hinder development or result in underdevelopment in the Third World and many scientific studies tried to determine these causes for deadlock in development. The current public and scientific attention has focused on transnational corporations, the major players in the world economy, as possible source of delayed development or even underdevelopment (while other opinions claim the opposite).

However, this interest is not particularly new. Since the early 1970s various research projects focused their analysis on the relationship between FDI - a measure for the activity by and presence of TNCs - in developing countries and the economic development of these poor host countries. The findings of these analyses are quite contradicting. Some assume beneficial effects resulting from FDI on economic development while others claim that FDI hinders economic development. Differences in these research results can be attributed to the diverging theoretical approaches, differences in data (for instance due to different data quality or differences in the composition of the sample, like varying sets of countries), diverging model setups, theory-based assumptions or the interpretation of empirical results, just to name a few.

Two dominant strains of theories pursue differing explanations for these sharply diverging long-run growth patterns. One strain argues that the answer lies in economic and political features of developing countries and the way these have changed over time in response to both world events and internal pressures. That is; that the low economic growth rate and development is homemade due to political instability, insecure property rights, and misguided economic policies (Barro and Sala-i-Martin 1995; Krugman and Obstfeld 2000). The other theoretical strain's main argument is that underdevelopment is a consequence of differential distribution of power between the Northern industrialized countries of the centre and the Southern countries of the periphery. Transnational corporations (TNCs) are seen as the major economic agents who are interested in maintaining the differences in development. The excerpt from the interview with the former Malaysian prime minister, Mahathir bin Mohamad, reflects this position in a rather generalized manner by emphasizing that TNCs are profit oriented 
enterprises, which are too strong for domestic enterprises to compete with and whose activities solely serve their own interests. Since the number of TNCs has been constantly increasing and the economic size of some TNCs trumps the size of whole economies, the trend towards an increasingly globalized economy is undamped. Therefore, the theoretical assumptions of development-theories regarding the role of TNCs in the world economy require continuous empirical analysis.

\section{Statement of Problem}

Multinational corporations operate at the crossing point between production, international trade and foreign investments. These companies are in the middle of the debates about economic globalization. They are known as transnational corporations or as multinational firms too. Multinational Corporation is a firm which control and organize production using plants from at least two countries (Caves, 1996:1). UNCTAD consider that the number of multinational corporations is about 63000. They have 700000 branches in other countries. These multinational corporations and their branches have $25 \%$ from world output and 86 millions of labour. Practically, 2/3 from world exports of goods and services are made using multinational corporations (Dunning, 2003: 77).

An important part of this international trade is unfurled between firms, multinational corporations and their branches from other countries. For example, $33 \%$ of exports and $40 \%$ of imports are unfurled between firms in U.S.A. (Grimwade, 2000:134). In the last twenty years, the importance of the multinational corporations in world economy grew up. Foreign direct investments of these multinational corporations grew up from 180 billion USD in 1980 to 1000 billion USD in 2000. In 2002, for example, the stock of foreign direct investments was about 7100 billion USD, given the situation of 802 billion USD in 1982 (UNCTAD, 2003).

The activity of multinational corporations supports economic globalization. But their impact on developing economies isn't a positive every time. Multinational corporations deals with economic efficiency and exploit the scale economies. As a result, their branches migrate from those countries which have strict regulations about corporations to other countries with a permissive legislation. In order to break this process, the developing countries are forced to reduce the restrictions for multinational corporations connected with taxes, labour and environment protection. There is a contradiction between the wish of the multinational corporations to maximize their profits and national legislation from those countries in which the multinational corporations operate.

Nowadays, the elements which support the placement of the multinational corporations in a country are: market expansion, consumption zones proximity, following competition and decrease of costs. In world economy, we can assist to a race for decreasing restrictions of the developing countries against multinational corporations, in order to obtain advantages for their citizens as a result of branches' place to their national territory. More, we talk about a race to the bottom, which means progressive migration of the capitals and technologies from countries with high levels of wages and regulations to other countries with regulations which are more favourable for multinational corporations. But for many developing countries, multinational corporations represent the lowest bad thing which they can select. For these countries, the multinational corporations create new jobs, develop infrastructure and stimulate the demand growth.

On the other hand, there are a lot of favourable factors for acceleration of the race to the bottom. One of these factors is mobility. The multinational corporations are able to migrate across national boundaries. This process is easy in those countries in which national boundaries control is minimal. The process was initiated in industrial era and developed after the Second World War concomitantly with GATT's initiatives for world trade promotion. As a result, trade tariffs and capitals control decreased, for the beginning in developed countries and after that in developing countries. Another effect was the introduction of new regulations about intellectual propriety rights. Another factor which supported the acceleration of the race to the bottom was the decrease of taxes and wages in other countries in order to attract branches of international corporations.

At last, we can mention the decrease of input prices and the relaxation of restrictions against multinational corporations. On the other hand, there are new favourable conditions for multinational corporations' branches placement. The first condition is goods' homogeneousness. The companies which produce the same good have the same internal structure of the costs and are obliged to compete one against other using marginal costs and relative advantages.

On the one hand, dependency theorists and environmentalists are generally pessimistic about the contributions of MNCs to the protection of the natural environment, particularly in host developing countries. For these schools of thought, the profit-maximising nature of multinational enterprises as well as their extensive marketing networks suggests that MNCs would try to move their unwanted products from one country to another until a market is found for such products (ESCAP/UNCTC, 1988:12). Due to their urgent need for employment opportunities, low-income countries are often compelled to set lax environmental standards in order to attract foreign 
investors. This problem, coupled with the high costs of conforming to the more stringent environmental standards in the advanced world, means that developing countries are likely to remain the "havens" of the pollution-intensive industries of the multinational firms of the developed world.

This argument does not only sound good in theory. Instead, a number of empirical studies have supported the relocation of "dirty industries" to developing countries. For example, during the 1970 s, there was a trend to locate new capacities of the Japanese aluminium industry abroad due to environmental considerations (Walter, 1975). In sharp contrast to the above assessment, neo-liberal economists contend that MNCs are perhaps the most significant catalysts for sustainable development, because multinational corporations typically possess newer and cleaner technology and have better management practices which can be transferred to their subsidiaries in the developing world. Thus, rather than "pollution havens", MNCs create "pollution halos" in developing countries through the export of modern technologies. In support of the pollution halo hypothesis, Eskeland and Harrison (1997) found that foreign ownership was associated with cleaner and lower levels of energy use in Mexico, Venezuela and Cote d'Ivoire. Similarly, Blackman and Wu (1998) found significant support for the conclusion that foreign investment in electricity generation in China increased energy efficiency and reduced hazardous emissions.

The above fundamentally divergent positions clearly demonstrate the need for further investigation about the real impact of MNCs on the environment of the developing world. This is particularly so because these seemingly logical, yet contradictory positions put the policy-maker in a dilemma. How should policy makers reconcile these positions to make appropriate policies towards MNCs? Should multinational enterprises be viewed as inherently detrimental to the advancement of sustainable development? How can the contributions of MNCs to sustainable development be enhanced? Are they a blessing or a burden.

Spicer (2002), executive vice president of corporate affairs at Anglo American, suggests that the most effective and efficient way of enhancing MNC contribution to sustainable development is through voluntary approaches rather regulation, because 'you can't regulate virtue'. This paper however takes a contrary view by arguing that the fact that 'the self- interest of a corporation and the need to enhance shareholder value takes precedence over concern for the community as a whole' (Shaughnessy, 2000: 163-64) means that industry self-regulation is likely to be effective only when it coincides with the profit motives of multinationals. It is apparent that potential polluters cannot make laws and sanction themselves when they go against those laws. Thus, to the extent that the raison d'etre of every business entity is to maximise profit, MNCs need to be regulated if we are to turn them into a more positive force for good in the promotion of sustainable development. As to what constitutes the appropriate forum of regulating MNCs, it has been suggested that host developing countries can, and must remain primarily responsible for regulating foreign corporate activity because they are the most affected by environmentally-harmful corporate practices.

While the above line of argument is not necessarily new, a major departure of this paper from extant literature is its emphasis on the inevitability of the multinational corporations on developing economies in their quest for sustainable economic development.

The paper is structured as follows: Sections 2 and 3 define and provide some stylized facts about multinational corporations and sustainable development respectively. Section 4 appraises the role of MNCs on sustainable development with particular reference to host developing countries. Section 5 focuses on the environmental records of Royal Dutch Shell in Nigeria's Niger Delta because of the international notoriety it has received over the past two decades. Section 6 outlines the weaknesses of business-led voluntary codes in promoting sustainable development, and therefore emphasises the need for effective regulatory mechanisms both domestically and internationally. Section 7 concludes the paper.

\section{Objectives of study}

Our objective in this study is to find out the truism of the inevitable roles Multinational Corporations plays in the quest of developing economies like Nigeria for desired and sustainable development.

\section{Research Hypotheses}

The hypotheses that shall guide this study are as presented in Null and Alternative form below:

Null Hypothesis: Multi-National Corporations cannot bring desired and sustainable development to the developing economies.

Alternative Hypothesis: Multi-National Corporations can bring desired and sustainable development to the developing economies

\section{Conceptual and theoretical Framework}

Multinational corporations: Meaning and some stylized facts

Although the modern MNC has its roots in the East and West Indies traders of the mercantilist era 
(UNCTAD, 2002:2), the term multinational corporation first appeared in 1960. Distinguishing between portfolio and direct investment, Lilienthal (1960:119) first used the term to refer to 'such corporations...which have their home in one country but which operate and live under the laws of other countries as well'. Two major features are associated with MNCs: first, their activities involve more than one nation; second they are responsible for most foreign direct investment (FDI). For Dunning (1996), therefore, any corporation that engages in FDI and owns or controls value-adding activities in more than one country is a multinational corporation.

The period 1970-2000 saw an enormous growth of activity by multinational enterprises. While only 7,000 MNCs existed in 1970 (Kolodner, 1994:2), there were as many as 63,000 parent firms with around 690,000 foreign affiliates by the year 2000 (UNCTAD, 2000:37). MNCs have been expanding not only numerically but also financially. In 1998, the annual revenues of the top 5 corporations more than doubled the gross domestic product (GDP) of the 100 poorest countries in the world (UNCTAD, 2002:3).

The sheer size and enormous economic power of MNCs $s$ means they have the capacity to influence development policy. Due to the perceived benefits associated with them, political and economic decisions by elected governments are increasingly made to provide favourable environments for the investment and marketing needs of MNCs. Consequently, corporations are sometimes able to influence the domestic policy outcomes of host developing countries by threatening to move jobs overseas. This often raises questions about whether corporate power enables MNCs to effectively undermine sustainable development by circumventing domestic environmental standards. Moreover, the fear that firms will move jobs overseas and the calculation of the effect that this could have on the economy, can influence the degree to which developing countries will impose environmental regulations on multinational enterprises (Porter, 1999).

The extraordinary growth of MNCs also enables them to influence policy outcomes at the international level. At many international fora, corporate lobbies have pushed for policies that will benefit business enterprises and let them get away with harming the environment. In the run-up to Rio, for example, corporate groups were active in defining the concept of sustainable development and pressing for their interpretation of corporations as promoters of sustainable development to be represented in the official documentation coming out of the conference (Chaterjee and Finger, 1994). The interests of the various giant corporations in the auto, mining, oil and chemical industries also influenced the Kyoto Global Climate Change
Conference outcome (Shah, 2002). By influencing the terminology in a way that enables them to promote faith in industry self-regulation, MNCs have thus far succeeded in escaping calls for direct regulation of their activities. At Rio in particular, corporations ensured that the only references to them in Agenda 21 were in the context of corporations as partners in sustainable development or in the promotion of voluntary codes (Finger and Kilcoyne, 1997). In this way, no explicit obligations or regulations were placed on these actors in the follow up to Rio.

\section{An Overview of the Nigerian Economy}

Nigeria is a middle income, mixed economy and emerging market, with expanding financial, service, communications, and entertainment sectors. It is ranked 30th (40th in 2005, 52nd in 2000), in the world in terms of GDP (PPP) as of 2012, and 2nd largest within Africa (behind South Africa), on track to becoming one of the 20 largest economies in the world by 2020 . Its re-emergent, though currently underperforming, manufacturing sector is the third-largest on the continent, and produces a large proportion of goods and services for the West African region.

Previously hindered by years of mismanagement, economic reforms of the past decade have put Nigeria back on track towards achieving its full economic potential. Nigerian GDP at purchasing power parity (PPP) has almost trebled from $\$ 170$ billion in 2000 to $\$ 451$ billion in 2012 , although estimates of the size of the informal sector (which is not included in official figures) put the actual numbers closer to $\$ 630$ billion. Correspondingly, the GDP per capita doubled from $\$ 1400$ per person in 2000 to an estimated $\$ 2,800$ per person in 2012 (again, with the inclusion of the informal sector, it is estimated that GDP per capita hovers around $\$ 3,900$ per person). (Population increased from 120 million in 2000 to 160 million in 2010). These figures might be revised upwards by as much as $40 \%$ when the country completes the rebasing of its economy later in 2013.

Although much has been made of its status as a major exporter of oil, Nigeria produces only about $2.7 \%$ of the world's supply (Saudi Arabia: $12.9 \%$, Russia: $12.7 \%$, USA:8.6\%). To put oil revenues in perspective: at an estimated export rate of 1.9 $\mathrm{Mbbl} / \mathrm{d}\left(300,000 \mathrm{~m}^{3} / \mathrm{d}\right)$, with a projected sales price of $\$ 65$ per barrel in 2011, Nigeria's anticipated revenue from petroleum is about $\$ 52.2$ billion (2012 GDP: \$451 billion). This accounts about $11 \%$ of official GDP figures (and drops to $8 \%$ when the informal economy is included in these calculations). Therefore, though the petroleum sector is important, it remains in fact a small part of the country's overall vibrant and diversified economy. 
The largely subsistence agricultural sector has not kept up with rapid population growth, and Nigeria, once a large net exporter of food, now imports a large quantity of its food products, though there is a resurgence in manufacturing and exporting of food products. In 2006, Nigeria successfully convinced the Paris Club to let it buy back the bulk of its debts owed to the Paris Club for a cash payment of roughly $\$ 12$ billion (USD).

\section{Review of Previous study}

\section{Sustainable development}

Until the 1980s, opinions about MNCs as development agents were largely influenced by the orthodox view among free market economists that MNCs are legally accountable only to their shareholders for the financial performance of the corporation. This view considered multinationals as purely profit-minded entities that did not have any legal obligation in incorporating society's interest into their activities. Friedman (1970:126) eloquently expressed this view thus: 'there is one and only one social responsibility of business - to use its resources and engage in activities designed to increase its profits...'

From the 1980s, however, a series of environmental catastrophes associated with the activities of MNCs coupled with the recognition that humanity's survival is largely dependent on the continued functioning of the natural environment (Disseindorf, 2000), resulted in a considerable shift in thinking regarding the role of MNCs in society. Given that MNCs are the most important players involved in environmentally damaging activities (Third Wold Network [TWN], 1997), many scholars now question the traditional model of "business as usual" and call upon business enterprises to place the long-term sustainability of the environment alongside their narrow commercial interests. This idea of balancing corporate interest with environmental protection has given rise to what has become known as sustainable development.

From an international perspective, although issues concerning environmental sustainability were first raised by the 1972 Stockholm Declaration, the term was first used by the WECD [World Commission for Environment and Development] (1987:43) to refer to any form of development that 'meets the needs of the present without compromising the ability of future generations to meet their own needs'. From the business perspective, and for the purpose of this paper, sustainable development means the adoption of 'business strategies and activities that meet the needs of the enterprise and its stakeholders today while protecting, sustaining and enhancing the human and natural resources that will be needed in the future' (Brkic and Douglas, 1997:33).

\section{The role of multinational corporations in sustainable development: An appraisal}

Over the years, it has since remained an issue of debate if truly multinational corporations play any significant role in bringing development to their host countries particularly the developing economies. Some previous studies have posed such questions as; does increase multinational investment lead to environmental sustainability? Or is there a trade-off between multinational corporations and sustainable development? It is widely accepted that technological progress is an important factor in protecting the natural environment. Technological advancement may contribute to reducing environmental externalities in two major ways: first, high level of technology can help in the manufacture of products which are less environmentally damaging to use or dispose of (e.g. fuel-efficient vehicles); second, through sophisticated technology, pollutants may be emitted less intensively (UNCTAD, 1999:15). Warhust and Bridge (1997) also suggest that technological innovations such as energy-efficient "flash" smelters, biotechnology-based leaching alternatives to smelting are substantially reducing the overall use of resources and the damage to water, land, air and ecosystems

If it is accepted that increased technology can contribute to improved environmental management capacity, then it might as well be that MNCs are the key to achieving sustainable development, because they are the main transmission mechanisms of technology to developing countries. In 1995 alone, over 80\% of global royalty payments and licence fees were by MNC subsidiaries to their parent companies (UNCTAD, 1997)13. Indeed, MNCs are not only the major technology innovators, but they also possess skills in the safe handling, transport, storage, use and disposal of toxic materials, and in the development of pollution abatement technologies (Morimoto, 2005).

Moreover, multinational enterprises can positively contribute to sustainable development through the transfer of environmental managerial skills that are not available to host developing countries. As DiConti (1992:107) writes: 'Through its empowerment of indigenous professionals and managers, multinational corporate subsidiary transfers knowledge and experiences that are less available locally'. In support of this argument, Eriksen and Jansen (1998) draw our attention to the international environmental activities in China, from Novo Nordisk, (a Danish pharmaceutical MNC) which developed a joint venture with the Suzhou Hongda Group in the production of starch- 
degrading enzymes for the alcohol industry. As a result, untreated water is no longer discharged, but processed through biological wastewater treatment plants which reduced the organic material by 90 per cent14.

In sum, the technological advancements of MNCs, coupled with their high management skills, it is argued, places them at a greater advantage in enhancing the sustainability of the ecology. Thus, Schmidheiny (1992:9) concludes that "[g]iven the large technological and productive capacity of business, any progress toward sustainable development requires its active leadership". For developing countries in particular that do not have adequate resources for technological innovation, one can legitimately claim that the multinational corporation may not only be regarded as an important agent of sustainable development, but is also 'the only real hope' (Drucker, 1974:134).15

While there is little doubt that MNCs possess clean technologies than can enhance environmental sustainability, many scholars remain doubtful whether MNC technology is an unmitigated blessing to host developing countries. Because of their greater technological capacity, the use of production techniques or substances that are more ecologically damaging, and the larger volume of production that they characterise, MNCs usually have a negative effect on the environment when they newly produce in, or export to an area. With the increasing spread and market penetration and share of MNCs, the damaging environmental effects have increased. For example, these companies account for a large part of increased forest logging and deforestation in Indochina, the Pacific and South America (TWN, 1997). Moreover, it has been suggested that MNCs, in order reduce cost, apply inferior environmental technology, management practices and standards in their developing countries' subsidiaries. A large proportion of equipment transferred to developing countries, it is argued, is either too sophisticated for developing countries to be accustomed to, or too obsolete to reduce cost and increase efficiency. Moreover, MNCs supply technology and any other know-how to developing countries with very high prices16. From this perspective, multinational enterprises are said to perpetuate technological dependence other than aiding sustainable development.

However, the most significant aspect of the "inappropriateness" of MNC technology relates to their environmental and safety dimensions. Do MNCs export environmentally harmful technologies to their affiliates in poor countries? There are claims that due to the high environmental standards in developed countries, MNCs systematically shift their environmentally noxious operations to developing countries. For critics, industrial disasters such as the 1984 Bhopal catastrophe and the recent environmental practices of Shell in Nigeria's Ogoniland epitomize the environmental hazards underlying the operations of MNCs.

Worse still, current international agenda suggest that there is no real will to change harmful production methods. Already, 'the costs and uncertainties of creating and applying new technologies from scratch are generally quite high and have to be borne by some entity, [either] business or government' (Venon, 1976: 43-44)17. However, given their insufficient financial resources, most developing countries lack the advanced and effective pollution control technologies required for environmental sustainability. Instead, investments in technology necessary for sustainable development can largely be obtained from foreign corporations. Unfortunately, however, the proposed Trade Related Aspect of Intellectual Property Rights agreement (TRIPS) at the WTO is likely to make the transfer of "clean" technologies much more expensive through excessive royalty fees. This will further increase the inability of developing countries to purchase "clean" technology, and ipso facto, further compel them to loosen their regulatory regimes in order to receive "dirty" technologies from the multinationals of the developed world. Indeed, evidence in many developing countries including China already suggests that indigenous enterprises accepted pollution-intensive equipments from developed countries because they were cheap (OECD, 1997).

Defenders of multinationals, however, maintain that the above claims often over stretch the environmental impacts of MNCs as though only foreign multinational companies engage in environmentally degrading activities. It is argued that multinational corporations are neither better nor worse than indigenous companies in their environmental practices. In a comprehensive study, UNCTAD (1988:228) finds that while the number of industrial accidents appears to have risen over the last fifteen years, available evidence indicates that multinational corporations have been involved in less than half of them. 'Many accidents have occurred in purely national firms or in state-owned enterprises' (Ibid).

Moreover, while it may be true that MNCs follow lower environmental standards in developing countries than in industrialized nations, there is respectable evidence that their environmental practices in developing countries are more responsible than local firms operating in such countries (UNCTC, 1992: 233-234). This line of thinking suggests that unless we recognize that large corporations in general are environmentally destructive, it would be somewhat unwarranted to conceive of MNCs as purely antithetical to sustainable development on the basis that their activities destroy the environment. 
This argument can however be misleading from one critical dimension. To be sure, that local firm also sometimes engage in environmentally deteriorating activities does not provide any justification for MNCs to continuously shift their obsolete technologies to developing countries without adequate safety measures. This is particularly so because multinational firms possess greater technical, financial, and organizational resources needed to solve environmental problems, and must therefore bear an enhanced responsibility to promote environmentally sustainable practices than their local counterparts (UNCTC, ibid: 226; Shrivastava, 1995)19. In this context, using the activities of local firms in assessing MNC environmental practices can be misleading.

From the above theoretical discussion, it appears that if environment concerns were central in MNC decision makings, then corporations could be the best sustainers of the environment. However, the empirical evidence reviewed in the next section suggests that despite the capabilities of MNCs in implementing higher environmental standards, their contribution towards this course in host developing countries is quite abysmal.

\section{Research Methodology}

\section{Data sources}

Based on the nature of the study, data collection sources were secondary in nature. The study sourced data from Statistics Bulletin of the Central Bank of Nigeria (CBN), Federal Office of Statistics (FOS) and Annual Abstract of Statistics of the National Bureau of Statistics (NBS) for about 42 years covering the period between 1970 and 2011 .

\section{Model Specifications}

In specifying our model, our dependent variable is the annual time series data of the Gross Domestic Product (GDP) as proxy for sustainable economic development for the period between 1970 and 2011, while our explanatory variable is the annual time series data of the Foreign Direct Investment (FDI) as proxy for Multinational Corporations (MNCs) covering the period between 1970 and 2011 as well. This is because the contribution of Multinational Corporations should reflect in the consistent growth in the Gross Domestic Product (GDP) given the period under review. Therefore, our model can be specified as thus;

$\mathrm{GDP}=\mathrm{b}_{0}+\mathrm{b}_{1} \mathrm{X}_{1}+\mathrm{U}$

Where,

GDP $=$ Gross Domestic Product (GDP)

$\mathrm{X}_{1}=$ Foreign Direct Investment (FDI)

$\mathrm{U}=$ The stochastic error term

\section{Research Technique}

As such, we shall make use of the Ordinary Least Square (OLS) multiple regression technique to estimate the values of the parameters Bo, $B_{1}$. Besides, we will use the student's t-values obtained to determine the statistical significance of the parameter estimates and the test of goodness of fit for the model using the $\mathrm{R}^{2}$ technique. This will enable us to know the percentage of variations between the dependent variable and the explanatory variables.

Then, the F-statistic test to determine the overall significance of the multiple regression models and the Durbin -Watson test for the presence or absence of autocorrelation.

\section{Presentation of results}

Our Ordinary Least Square (OLS) simple regression results are as presented below:

$\begin{array}{lcc}\text { GDP }= & -6.99 \mathrm{E}+08+ & \text { 6583.46 FDI } \\ \mathrm{S} . \mathrm{E} & (1.63 \mathrm{E}+08) & (135.44) \\ \mathrm{t} & -4.28 & 48.61 \\ \text { Prob. } \quad(0.00) & (0.00) \\ \mathrm{R}^{2}=0.98, \text { F-stat=2362.77 } & (0.00), \mathrm{DW}=0.23 \mathrm{~N}=42\end{array}$

\section{Discussion of results}

The empirical results generated from the estimation as presented above are revealing and in fact instructive. The $\mathrm{R}^{2}$ which is the coefficient of determination was found to be very high at 0.98 , implying a $98 \%$ explanation of variations between our dependent and independent variables. Likewise, the F-statistics was also found to be very high indicating in the overall the high significance of our research model.

With regards to the t-value, it was found that the Foreign Direct Investment (FDI) recorded given the period of study, has a statistically significant impact on economic growth in Nigeria. The sign of the estimated coefficient was positive with a very high t-value of 48.61 suggesting that FDI has greatly impacted on the Nigerian economy. This is an indication that FD investments in Nigeria have to a large extent justified its presence and have also promoted sustainable economic growth in the country.

It is worthy of note from the result obtained and presented that the intercept was negatively related to the GDP i.e. to economic growth. In addition, it was found to be statistically significant in its negative form, the implication of this, is that when the FDI was at point zero, economic growth in Nigeria was at its lowest ebb and a negative one. Intuitively, the presence of FDI has greatly improved the economic growth status of Nigeria given the period of study. 


\section{Conclusion}

This paper dwells on the inevitability of multinational corporations in the sustainable development of developing economies, using Nigeria as a case study. Over the years and with the advent of globalization, multi-national corporations now move with ease across the world to economy of interest, most often times to developing economies. Obviously speaking and considering the huge amount and the technicalities involve in setting up these multi-nationals, it is obvious that the developing economies cannot do without them. The study revealed that the presence of FDIs have greatly impacted positively and significantly on the Nigerian economy given the period of study. This is true to apriori and theoretical propositions.

\section{Recommendations}

To maintain this feat, and to also keep the Nigerian economy on the path of continous and sustainable growth and development, the government must put in place an enabling environment for FDI to thrives and at the same time come up with policies that are favourably disposed towards these multinationals. However, caution must also be exercised so that it will not be at the detriment of local industries and the people of the country particularly their host communities as the case with the Niger-Delta region. This is very important, because we cannot claim of ignorance of some of the environmental hazards that some of these multinational corporations to their host communities. Therefore, as an addendum control measure policies should be put in place by the government to compensate for such hazards in several of the host communities of these multinational corporations..

\section{References}

Aghion, Philippe and Peter Howitt. 1998. Endogenous Growth Theory. Cambridge (Mass.):The MIT Press.

Agosin, Manuel R. and Ricardo Mayer. 2000. "Foreign Direct Investment in Developing Countries. Does it Crowd in Domestic Investment?" UNCTAD, Geneva.

Ballmer-Cao, Thanh-Huyen and Jürg Scheidegger. 1979. "Compendium of Data Based on the Study of MNCs, Economic Policy and National Development." in Sondernummer des

Bulletins des Soziologischen Instituts, Universität Zürich. Zürich: Soziologisches Institut, Universität Zürich.

Barro, Robert J. and Xavier Sala-i-Martin. 1995. Economic growth. Cambridge (MA): MIT Press.

Boeckh, Andreas. 1993. "Vier Jahrzehnte Entwicklungstheorie und Entwicklungspolitik." Pp.109-130 in Handbuch der Dritten Welt. Grundprobleme, Theorie und Strategien, vol.1, edited by D. Nohlen and F. Nuscheler. Bonn: Verlag J.H.W. Dietz.

Bornschier, Volker. 2002. Weltgesellschaft - Grundlegende soziale Wandlung. Zürich: Loreto Verlag.

Bornschier, Volker and Christopher Chase-Dunn. 1985. Transnational Corporations and Underdevelopment. New York: Praeger.
Bornschier, Volker, Christopher Chase-Dunn, and Richard Rubinson. 1978. "Cross-national Evidence of the Effects of Foreign Investment and Aid on Economic Growth and Inequality: A Survey of Findings and a Reanalysis." American Journal of Sociology84:651-683.

Bretschger, Lucas. 1998. Wachstumstheorie. München: R. Oldenbourg Verlag.

Cardoso, Fernando H. and Enzo Faletto. 1976. Abhängigkeit und Entwicklung in Lateinamerika. Frankfurt: Suhrkamp Verlag.

Chase-Dunn, Christopher. 1989. Global Formation. Structures of the World-Economy. Cambridge, MA: Basil Blackwell Inc.

de Soysa, Indra and John R. Oneal. 1999. "Boon or Bane? Reassessing the Productivity of Foreign Direct Investment." American Sociological Review 64:766-782.

Dixon, William J. and Terry Boswell. 1996a. "Dependency, Disarticulation, and Denominator Effects: Another Look at Foreign Capital Penetration." American Journal of Sociology 102:543-562.

-. 1996b. "Differential Productivity, Negative Externalities, and Foreign Capital Dependency: Reply to Firebaugh." American Journal of Sociology 102:576-584.

Dunning, John H. 1992. Multinational Enterprises and the Global Economy. Wokinham: Addison Wesley.

Evans, Peter B. 1985. "Transnational Linkages and the Economic Role of the State: An Analysis of Developing and Industrialized Nations in the Post-World War II Period."in Bringing the State Back In, edited by P. B. Evans, D. Rueschemeyer, and T.Skocpol. Cambridge: Cambridge University Press.

—. 1989. "Predatory, Developmental, and other Apparatuses: A Comparative Political Economy Perspective on the Third World State." Sociological Forum 4:561-587.

Firebaugh, Glenn. 1992. "Growth Effects of Foreign and Domestic Investments." American Journal of Sociology 98:105-130.

—. 1996. "Does Foreign Capital Harm Poor Nations? New Estimates Based on Dixon and Boswell's Measures of Capital Penetration." American Journal of Sociology 102:563-575.

Grunlach, Erich. 1994. "Accounting for the Stock of Human Capital: Selected Evidence and Potential Implications." Weltwirtschaftliches Archiv 130:350-374.

- 1995. "The Role of Human Capital in Economic Growth: New Results and Alternative Interpretations." Weltwirtschaftliches Archiv 131:383-402.

Herkenrath, Mark. 2003. Transnationale Konzerne im Weltsystem. Globale Unternehmen,Nationale Wirtschaftspolitik und das Problem Nachholender Entwicklung. Wiesbaden: Westdeutscher Verlag.

Heston, Alan, Robert Summers, and Bettina Aten. 2002. Penn World Tables Version 6.1. University of Pennsylvania: Center for International Comparison.

International Monetary Fund. 1992. Balance of Payments Statistics Yearbook, vol. 43. Washington: IMF.

—. 1993. Balance of Payments Manual: IMF.

Kentor, Jeffrey. 1998. "The Long-Term Effects of Foreign Investment Dependence on Economic Growth, 19401990." American Journal of Sociology 103:1024-1046.

Kiely, Ray. 1998. "Transnational companies, global capital and the Third World." Pp. 45-66 in Globalisation and the Third World, edited by R. Kiely and P. Marfleet. London:Routledge.

Krugman, Paul. 2003. "The Good News." in The New York Times. New York.

Krugman, Paul R. and Maurice Obstfeld. 2000. International Economics: Theory and Policy. Reading (Mass.): AddisonWesley.

Lexikon Dritte Welt. 1993. Länder, Organisationen, Theorien, Begriffe, Personen, Edited by D. Nohlen. Reinbek bei Hamburg: Rowolth Taschenbuch Verlag.

Maddison, Angus. 2001. The World Economy: A Milllennial Perspective: Development Centre Seminars of the OECD. 
Mahathir bin Mohamad, Datuk Seri. 1999. "Interview with the Malaysian Prime Minister: "We had to decide things for ourselves." Executive Intelligence Review.

Mankiw, Gregory N. 1995. "The Growth of Nations." Brooking Papers on Economic Activity 1:275-326.

Mankiw, Gregory N., David Romer, and David N. Weil. 1992. "A Contribution to the Empirics of Economic Growth." The Quarterly Journal of Economics May:407-437.

Mansilla, Hugo C.F. 1986. Die Trugbilder der Entwicklung in der Dritten Welt. Elemente einer kritischen Theorie der Modernisierung, vol. 7, Edited by M. Molls, D. Nohlen, and P. Waldmann. Paderborn: Ferdinand Schönigh.

Menzel, Ulrich. 1993. "40 Jahre Entwicklungsstrategie $=40$ Jahre Wachstumsstrategie." Pp.131-155 in Handbuch der Dritten Welt. Grundprobleme, Theorien und Strategien, vol. 1, edited by D. Nohlen and F. Nuscheler. Bonn: Verlag, J.H.W. Dietz.

Murthy, Vasudeva N.R. and Victor Ukpolo. 1999. "A Test of the Conditional Convergence Hypothesis: Econometric Evidence from African Countries." Economic Letters 65:249-253.
Nohlen, Dieter and Franz Nuscheler. 1993. "Was heisst Unterentwicklung." Pp. 31-54 in Handbuch der Dritten Welt, vol. 1, edited by D. Nohlen and N. Franz. Bonn: Verlag J.H.W Dietz.

Nussbaumer, Hannes and Gaby Szöllösy. 2003. "Alles Sektiererische liegt mir fern." in Tagesanzeiger. Zürich.

Pasinetti, Luigi L. 1981. Structural Change and Economic Growth. A Theoretical Essay on the Dynamics of the Wealth of Nations. Cambridge: Cambridge University Press.

Romer, David. 1996. Advanced Macroeconomics. New York: McGraw Hill.

Solow, Robert M. 1956. "A Contribution to the Theory of Economic Growth." Quarterly Journal of Economics 70:65-94.

Swan, Trevor W. 1956. "Economic Growth and Capital Accumulation." Economic Record 32:334-361.

UNCTAD. 1992. "World Investment Report 1992 Transnational Corporations as Engines of Growth." United Nations, Geneva. 


\section{Appendixes}

Table 1: Annual Time Series Data For Gdp And Foreign Direct Investment Into Nigeria 1970-2011.

\begin{tabular}{|c|c|c|c|}
\hline $\mathrm{S} / \mathrm{N}$ & YEAR & Gross Domestic Product (GDP) & Foreign Direct Invest. (FDI) \\
\hline 1 & 1970 & 5281.100 & 1003.200 \\
\hline 2 & 1971 & 6650.900 & 1322.800 \\
\hline 3 & 1972 & 7187.500 & 1571.100 \\
\hline 4 & 1973 & 8630.500 & 1763.700 \\
\hline 5 & 1974 & 18823.10 & 1812.100 \\
\hline 6 & 1975 & 21475.20 & 2287.500 \\
\hline 7 & 1976 & 26655.80 & 2339.000 \\
\hline 8 & 1977 & 31520.30 & 2531.400 \\
\hline 9 & 1978 & 34540.10 & 2863.200 \\
\hline 10 & 1979 & 41974.70 & 3153.100 \\
\hline 11 & 1980 & 49632.30 & 3620.100 \\
\hline 12 & 1981 & 47619.70 & 3757.900 \\
\hline 13 & 1982 & 49069.30 & 5382.800 \\
\hline 14 & 1983 & 53107.40 & 5949.500 \\
\hline 15 & 1984 & 59622.50 & 6418.300 \\
\hline 16 & 1985 & 67908.60 & 6804.000 \\
\hline 17 & 1986 & 69147.00 & 9313.600 \\
\hline 18 & 1987 & 105222.8 & 9993.600 \\
\hline 19 & 1988 & 139085.3 & 11339.20 \\
\hline 20 & 1989 & 216797.5 & 10436.10 \\
\hline 21 & 1990 & 267550.0 & 12243.50 \\
\hline 22 & 1991 & 312139.7 & 20512.70 \\
\hline 23 & 1992 & 532613.8 & 66787.00 \\
\hline 24 & 1993 & 683869.8 & 70714.60 \\
\hline 25 & 1994 & 899863.2 & 119391.6 \\
\hline 26 & 1995 & 1933212. & 122600.9 \\
\hline 27 & 1996 & 2702719. & 128331.9 \\
\hline 28 & 1997 & 2801973. & 152410.9 \\
\hline 29 & 1998 & 2708431. & 154190.4 \\
\hline 30 & 1999 & 3194015. & 157508.6 \\
\hline 31 & 2000 & 4582127. & 161441.6 \\
\hline 32 & 2001 & 4725086. & 166631.6 \\
\hline 33 & 2002 & 6912381. & 178478.6 \\
\hline 34 & 2003 & 8487032 . & 249220.6 \\
\hline 35 & 2004 & 11411067 & 324656.7 \\
\hline 36 & 2005 & 14572239 & 481239.1 \\
\hline 37 & 2006 & 18564595 & 552498.6 \\
\hline 38 & 2007 & 20657318 & 387261.3 \\
\hline 39 & 2008 & 24296329 & 399841.9 \\
\hline 40 & 2009 & 24712670 & 441271.3 \\
\hline 41 & 2010 & $3.40 \mathrm{E}+10$ & 5234383. \\
\hline 42 & 2011 & $3.75 \mathrm{E}+10$ & 5673950. \\
\hline
\end{tabular}

Source: Cbn Statistical Bulletin And National Bureau of Statistics

E-Views Software Analysis Results

Dependent Variable: GDP

Method: Least Squares

Date: 06/25/13 Time: 09:36

Sample: 19702011

Included observations: 42

\begin{tabular}{lrlrr}
\hline \multicolumn{1}{c}{ Variable } & Coefficient & \multicolumn{1}{c}{ Std. Error } & t-Statistic & Prob. \\
\multicolumn{1}{c}{ C } & $-6.99 \mathrm{E}+08$ & $1.63 \mathrm{E}+08$ & -4.283380 & 0.0001 \\
\multicolumn{1}{c}{ FD } & 6583.456 & 135.4388 & 48.60836 & 0.0000 \\
\hline R-squared & 0.983353 & Mean dependent var & $1.71 \mathrm{E}+09$ \\
Adjusted R-squared & 0.982936 & S.D. dependent var & $7.72 \mathrm{E}+09$ \\
S.E. of regression & $1.01 \mathrm{E}+09$ & Akaike info criterion & 44.34707 \\
Sum squared resid & $4.07 \mathrm{E}+19$ & Schwarz criterion & 44.42982 \\
Log likelihood & -929.2885 & F-statistic & 2362.772 \\
Durbin-Watson stat & 0.232609 & Prob(F-statistic) & 0.000000 \\
\hline
\end{tabular}

